\title{
Different Endometritis Treatments in Ewe: Comparative Study
}

\author{
Souhayla Oneeis Hussain ${ }^{1}$, Sulake Fadhil Al-Zubaidi ${ }^{2}$, Monther Asofi ${ }^{3}$ \\ ${ }^{I}$ (Surgery and obstetric department, Veterinary medicine college/Baghdad University, Iraq) \\ ${ }_{2}^{2}$ (Surgery and obstetric department, Veterinary medicine college/Al-Qasim green University, Iraq) \\ ${ }_{3}^{3}$ (Animal Resources department Agriculture college, Baghdad University, Iraq)
}

\begin{abstract}
The aim of this study is to find the best method of treatment of endometritis in ewe. The study was conducted in goat station at Agurgof and other region in Baghdad from 2009-2013 and was performed on 28 awassi ewes aged (2-4 years old) that diagnosed clinically as cases of endometritis. The animals were divided randomly into four groups each group consisting of 7 ewes. The first group was treated with oestradiol benzoate Img intramuscularly (IM) and $2 \mathrm{gm}$ of oxytetracycline $20 \%$ as intrauterine therapy; the second group was received oestradiol benzoate Img IM and $20 \mathrm{ml}$ of lugol's iodine solution intrauterinarly (IU). The third group was given oestradiol benzoate $1 \mathrm{mg} I M$ and 1 tube of cefapirin IU, while the fourth group was treated with $2 \mathrm{gm}$ oxytetracycline 20\% IM and oesradiol benzoate $1 \mathrm{mg} I M$. The results showed that the number of ewes responded were $(57.14,100,85.71$ and 42.85) \% respectively. The second and third groups showed the significant differences rather than first and fourth groups regarding to open days length. From these results, we concluded that oesradiol benzoate has vital role in the treatment of endometritis and its synergetic effect with lugol's iodine solution gives the best result.
\end{abstract}

Keywords: Ewe, Endometritis, Oestrogen, Oxytetracycline, Lugol's iodine, Cefapirin.

\section{Introduction}

Sheep form an important part of the livestock in Iraq, and sheep Awassi is the most important strain in the semi-arid lands of the Middle East countries [1]. Reproductive failure occurs in many different forms, as failure to return to heat, repeat breeding and small litter size and, sometimes, even severe disorders may be difficult to detect clinically. The most factors of infertility are structural, functional and management factors.

Endometritis was considered as one of the causes of subfertility in ewes [2, 3]. Endometritis refer to inflammation of endometrial lining of uterus, most inflammatory lesion of uterus are infectious in origin and result either from ascending infection by organism that normally inhibits the lower genital tract or infectious agents introduced in to the uterine cavity during mating, artificial insemination, or post-partum [4]. The clinical signs of endometritis include a thin, watery, possibly purulent, malodorous vaginal discharge, association with retained fetal membrane, dystocia, retained dead lambs, abortion caused by toxoplasmosis, chlamydiosis, and listeriosis [5, 6], or uterine infection by Corynebacterium pyogenes, Escherichia coli, Staphylococcus aureus, Pseudomonas aeruginosa, Klebsiella species, Proteus species, Streptococci species and Clostridium species being the isolates $[7,8]$. Recently, a study revealed that environmental bacteria were the most common isolates from cases of endometritis in cows: Enterococcus faecalis (36.2 \%), Streptococccus uberis $(19.1 \%)$ and Escherichia coli $(44.7 \%)$ [9].

Endometritis in ewes, as in cattle, is mostly common in the luteal phase or postpartum [10], and induces embryonic loss, as a result of uterine tissue disruption or direct embryo cytolysis [11]. In addition, the absorption of bacterial components can prevent the growth of Graafian follicles and ovulation [12]. There are several methods described for endometritis treatment in farm animals like logul's iodine, prostaglandin and systemic or local antibiotic $[13,14,15,16,17]$. This study was design to compare the efficiency of different methods for endometritis treatment (Table 1).

\section{Materials And Methods}

The study protocol was approved by the University Baghdad Research and postgraduate Committee. This study was conducted in goat station at Agurgof and other region in Baghdad city and 28 ewes aged 2-4 years old were used in duration from 2009-2013. Diagnosis of the disease was done by inspection of the pelvic region and vaginal examination using vaginal scope. Cases were divided randomly into four groups depending upon the type of treatment, each group composed of 7 ewes. The first group was treated with oestradiol benzoate $1 \mathrm{mg}$ injected intramuscularly (IM) and $2 \mathrm{gm}$ of oxytetracycline $20 \%$ as intrauterine therapy; the second group received oestradiol benzoate $1 \mathrm{mg}$ IM and $20 \mathrm{ml}$ of lugol's solution intrauterinarly (IU). The third group was given oestradiol benzoate $1 \mathrm{mg}$ IM and 1 tube of cefapirin (Metricure) ${ }^{\circledR} \mathrm{IU}$, while the fourth group was treated with $2 \mathrm{gm}$ of oxytetracycline $20 \% \mathrm{IM}$ and oestradiol bezoate $1 \mathrm{mg}$ IM. Response to treatment and length 
of open days was recorded. Reproductive criteria of animals were: nature and type of parturition, sex and number of lamb, viability of fetus and percentage of retained fetal membrane.

Mean standard deviation, chi square and T-test were conducted for data analysis.

\section{Results and Discussion}

The results of this study were illustrated in Table 1 and 2. Table 1 showed that the response of first, second, third, and fourth group to treatment were $(57.14,100,85.71$ and 42.85$) \%$ respectively and the best result were recorded in $2^{\text {nd }}$ group $(100 \%)$. Regarding the open days, it was found that there was significant $(P<0.05)$ differences between the $2^{\text {nd }}$ and $3^{\text {rd }}$ groups compared with $1^{\text {st }}$ and $4^{\text {th }}$ groups. The number of offspring was 14 male and 9 female out of treated ewes. Thirteen of pregnant ewes $(65 \%)$ had normal parturition and seven of pregnant ewes (35\%) suffered from dystocia. The percent of alive lambs was $69.4 \%$ and dead lamb was $30.5 \%$ from the total born lambs. Seventeen of pregnant ewes (85\%) had single lamb while three of pregnant ewes $(15 \%)$ had twin. The total percentage of retained placenta for the four groups was $30.43 \%$ (Table 2).The total response for treatment was $71.42 \%(20 / 28)$ and this response seems to be due to the vital role of oestradiole benzoate by increasing the uterine defense mechanism via enhancement the blood flow and local immunity of the uterus. An oestrogen based environment stimulates uterine contractility (and the resulting clearance in the contents of the uterus) and triggers an influx of neutrophils and immunoglobulins into the uterine mucosa [18, 19]. Moreover, oestrogen increases the release and metabolism of prostaglandin (PG) which enhance the myometrium contraction and uterine defense mechanism [20, 21]. It was found that the use of logul's iodine can stimulate myometrium contraction, blood supply and production of PGF2 $\alpha$ from uterus [22] and this effect may attributed to good response of the animals treated with logul's iodine in this study and this result agrees with L. Ramsingh et al [23]. The open days in the $2^{\text {nd }}$ and $3^{\text {rd }}$ groups compared with $1^{\text {st }}$ and $4^{\text {th }}$ groups was significantly $(P<0.05)$ varied and provide effective response to treatment. Possibly, this result may be due to beneficial effect of logul's iodine and cefapirin. Cefapirin, a first generation cephalosporin antibiotic, is active against grampositive organisms and anaerobic bacteria, but it is less active against gram-negative organisms. Therefore, cefapirin is the rational antibiotic choice for intrauterine infusion [24, 25, and 26]. Kasimanickam et al. [27] reported that a single treatment with cefapirin significantly improved the reproductive performance of cows with subclinical endometritis. Galvão [28] found that intrauterine administration of cefapirin benzathine was an effective treatment for clinical and subclinical endometritis. Furthermore, recent study found that cefapirin was a good therapy for endometritis [29].

Oxytetracycline is broad spectrum antibiotic and it is effective against many infections caused by Gram-positive and Gram-negative bacteria. Furthermore, oxytetracycline $20 \%$ has long duration of action (72 hours) $[30,31]$ providing good antibacterial coverage. Our findings may be due to synergistic effect of systemic and intrauterine antibiotics with oestradiol by stimulation of endometrial blood flow and increasing uterine leukocytic response [32]. This result agrees with Sengupta D and Nandi PR [33].

Table 1: Different regimen of treatment, response to treatment and open days in treated animals.

\begin{tabular}{|l|l|l|l|l|}
\hline Groups & $\begin{array}{l}\text { No. of treated } \\
\text { animals }\end{array}$ & Treatment regimen & $\begin{array}{l}\text { Response } \\
\text { No. } \\
\%\end{array}$ & $\begin{array}{l}\text { Open days } \\
\text { M } \pm \text { SE }\end{array}$ \\
\hline $1^{\text {st }}$ & 7 & $\begin{array}{l}\text { Oestradiol Benzoate } \\
1 \mathrm{mg}(1 \mathrm{ml})+2 \mathrm{gm}(10 \mathrm{ml}) \\
\text { oxyteracycline IU }\end{array}$ & $\begin{array}{l}4 \mathrm{~b} \\
57.14 \%\end{array}$ & $120 \pm 9.33 \mathrm{~b}$ \\
\hline $2^{\text {nd }}$ & 7 & $\begin{array}{l}\text { Oestradiol Benzoate } \\
1 \mathrm{mg}(1 \mathrm{ml})+\text { Logul's iodine } \\
(20 \mathrm{ml}) \mathrm{IU}\end{array}$ & $\begin{array}{l}7 \mathrm{a} \\
100 \%\end{array}$ & $108 \pm 10.2 \mathrm{a}$ \\
\hline $3^{\text {rd }}$ & 7 & $\begin{array}{l}\text { Oestradiol Benzoate 1 mg } \\
(1 \mathrm{ml}) \mathrm{I} / \mathrm{M}+\text { Metricure } 1 \\
\text { tube IU }\end{array}$ & $\begin{array}{l}6 \mathrm{a} \\
85.71 \%\end{array}$ & $112 \pm 9.31 \mathrm{a}$ \\
\hline $4^{\text {th }}$ & 7 & $\begin{array}{l}\text { Oestradiol Benzoate } 1 \mathrm{mg} \\
(1 \mathrm{ml})+\text { oxytetracycline } \\
20 \% \text { IM }\end{array}$ & $\begin{array}{l}3 \mathrm{c} \\
42.85 \%\end{array}$ & $138 \pm 8.21 \mathrm{c}$ \\
\hline Total & 28 & & $\begin{array}{l}20 / 28 \\
71.42 \%\end{array}$ & \\
\hline
\end{tabular}

*Different letters means significant differences $(P<0.05)$ 
Table 2: The effect of treatment on nature and type of birth, sex, viability of lambs and incidence of retained placenta.

\begin{tabular}{|c|c|c|c|c|c|c|c|c|c|c|c|}
\hline \multirow{2}{*}{$\begin{array}{l}\text { Grou } \\
\text { ps }\end{array}$} & \multirow{2}{*}{$\begin{array}{l}\text { No. } \\
\text { of } \\
\text { Ani. }\end{array}$} & \multirow{2}{*}{$\begin{array}{l}\text { No. of } \\
\text { pregn } \\
\text { ant } \\
\text { anima } \\
\text { ls }\end{array}$} & \multicolumn{2}{|c|}{$\begin{array}{l}\text { Nature of } \\
\text { parturition }\end{array}$} & \multicolumn{2}{|c|}{$\begin{array}{l}\text { Type of } \\
\text { parturition }\end{array}$} & \multicolumn{2}{|c|}{ Sex of lamb } & \multicolumn{2}{|c|}{ Viability } & \multirow{2}{*}{$\begin{array}{l}\text { Retaine } \\
\mathrm{d} \\
\text { placent } \\
\text { a } \\
\text { No. } \\
\%\end{array}$} \\
\hline & & & D & $\mathrm{N}$ & $S$ & $\mathrm{~T}$ & M & $\mathrm{F}$ & L & D & \\
\hline $1^{\mathrm{st}}$ & 7 & $\begin{array}{l}4 \\
57.14 \\
\%\end{array}$ & 2 & 2 & 4 & 0 & 2 & 2 & 1 & 3 & $\begin{array}{l}2 \\
50 \%\end{array}$ \\
\hline $2^{\text {nd }}$ & 7 & $\begin{array}{l}7 \\
100 \%\end{array}$ & 1 & 6 & 6 & 1 & 4 & 4 & 6 & 2 & $\begin{array}{l}2 \\
12.5 \%\end{array}$ \\
\hline $3^{\text {rd }}$ & 7 & $\begin{array}{l}6 \\
85.71 \\
\% \\
\end{array}$ & 1 & 5 & 4 & 2 & 6 & 2 & 7 & 1 & $\begin{array}{l}1 \\
12.5 \%\end{array}$ \\
\hline $4^{\text {th }}$ & 7 & $\begin{array}{l}3 \\
42.85 \\
\% \\
\end{array}$ & 3 & 0 & 3 & 0 & 2 & 1 & 2 & 1 & $\begin{array}{l}2 \\
33.3 \%\end{array}$ \\
\hline Total & 28 & $\begin{array}{l}20 \\
71.42 \\
\%\end{array}$ & $\begin{array}{l}7 \\
35 \\
\%\end{array}$ & $\begin{array}{l}13 \\
65 \\
\%\end{array}$ & $\begin{array}{l}17 \\
85 \\
\%\end{array}$ & $\begin{array}{l}3 \\
15 \\
\%\end{array}$ & $\begin{array}{l}14 \\
60.8 \\
\%\end{array}$ & $\begin{array}{l}9 \\
39.1 \\
\%\end{array}$ & $\begin{array}{l}16 \\
69.5 \\
\%\end{array}$ & $\begin{array}{l}7 \\
30.4 \\
\%\end{array}$ & $\begin{array}{l}7 \\
30.43 \%\end{array}$ \\
\hline
\end{tabular}

$\mathrm{N}=$ normal, $\mathrm{D}=$ dystocia, $\mathrm{S}=$ single, $\mathrm{T}=$ twin, $\mathrm{M}=$ male, $\mathrm{F}=$ female, $\mathrm{L}=$ alive, $\mathrm{D}=\mathrm{dead}$

\section{Conclusion}

We conclude that combination of IM oestadiol benzoate with logul's iodine solution as intrauterine therapy was effective in the treatment of endometritis in ewes since both drugs result in enhancement of uterine tonicity and contractility besides increasing uterine immunity resulting in evacuating the infection.

\section{References}

[1] Lafi S. Q. A. Q. Talafha \& N. Giadinis \& E. Kalaitzakis \& K. ourliotis \& N. Panousis. Factors affecting the reproductive performance of Awassi sheep flock in north-east of Jordan: An epidemiological study. Trop Anim Health Prod, 2009; 41:17551764 .

[2] C. Palmieri E. Schiavi, and L. Della Salda. Congenital and acquired pathology of ovary and tubular genital organs in ewes: A review. Therio, 2011; 75(3): 393-410.

[3] Keith Smith. Infertility in the Ewe and Doe (Female Goat). In: D. E. Noakes, T. J. Parkin-on and G. C. W. England, eds. Veterinary reproduction and obstetrics. $9^{\text {th }}$ ed. China: Elsevier Limited, 2009; 557.

[4] Tomas, J., Ronald H. and Norbal K. (1996).Veterinary pathology, genital system. $6^{\text {th }}$. ed. 1173-1176.

[5] Scott PR et al. The use of combined xylazine and lidocaine epidural injection in ewes with vaginal or uterine prolapse, Therio, 1995; 43:1175.

[6] Rowe J.D. Reproductive management—Part III. Small ruminants for the mixed animal practitioner, Small Ruminants for the Mixed Animal Practitioner Western Veterinary Conference 1998; 147.

[7] N.R. Adams.A. Pathological and bacteriological abattoir survey of the reproductive tracts of merino ewes in Western Australia. Aust Vet $J, 1975$; 51(7): 351-354.

[8] Udhayavel S, Malmarugan S, Palanisamy K and Rajeswar J. Antibiogram pattern of bacteria causing endometritis in cows. Vet World 2013; 6(2): 100-102.

[9] Jūrate šiugždaité, vilmantas juodžentis, saulius petkevičius. Bacterial contamination of the uterus in different lactation cows on endometritis. Vet Med Zoot, 2013; 61(83): 1392-2130.

[10] A.A. Ramadan, G.L. Johnson 3rd, G.S. Lewis. Regulation of uterine immune function during the estrous cycle and in response to infectious bacteria in sheep. J Anim Sci, 1997; 75(6): 1621-1632.

[11] K.E. Dawood. Pathological abnormalities of the reproductive tracts of ewes in Basra. Iraq Vet Rec, 2010; 166(7): 205-207.

[12] I.M. Sheldon, H. Dobson. Postpartum uterine health in cattle. Anim Reprod Sci, 2004; 82-83: 295-306.

[13] E. A. S. Alyasiri. A comparative study between different endometritis treatments in Goats. J Al-Anbar Agr Sci, 2011; 4(2): 22-25.

[14] Sarkar, A.K. Treatment of anoestrus cows with diluted Logul's iodine and massage on reproductive organs - uncontrolled case study. Journal of Animal and Veterinary Advances, 2005; 4(8): 734-736.

[15] O.I. Azawi, S.N. Omran and J.J. Hadad. A Study of Endometritis Causing Repeat Breeding of Cycling Iraqi Buffalo Cows. Reprod Dom Anim, 2008; 43: 735-743.

[16] Stephen J. LeBlanc. Postpartum uterine disease and dairy herd reproductive performance: A review. Vet J, 2008; 176(1): $102-114$.

[17] T. B. Kaufmann, S. Westermann, M. Drillich, J. Plöntzke, W. Heuwieser. Systemic Antibiotic Treatment of Clinical Endometritis in Dairy Cows with Ceftiofur or two Doses of Cloprostenol in a 14 day Interval. Animal Reproduction Science, 2010; 121(1-2): 55-62.

[18] Lefebvre, R. and A. Stock. Therapeutic Efficiency of Antibiotics and Prostaglandin F2 $\alpha$ in Postpartum Dairy Cows with Clinical Endometritis: An Evidence-Based Evaluation. Veterinary Clinics of North America: Food Animal Practice, 2012; 28: 79-96.

[19] M. S. Akhtar, A. A. Farooq and S. Ina. Treatment of first degree endometritis by cloprostenol and estradiol in choolistani cows. The Journal of Animal \& Plant Sciences, 2009; 19(1): 20-21.

[20] Araujo, R. R., Ginther, O. J., Ferreira, J. C., Palhao, M. M., Beq, M. A., Wiltbank, M. C. Role of follicular estradiol-17beta in timing of luteolysis in heifers. Biol of Pepro, 2009; 81(2): 426- 37.

[21] G. S. Lewis. Role of ovarian progesterone and potential role of prostaglandin. $J$ Anim Sci, 2003; 81:285-293.

[22] Al-Hamedawi T.M. PostPartum Pyometra in Iraqi Goats: Clinical \& Therapeutical Study. The Iraqi J Vet Med, 2011; 35 (2): 36 39. 
[23] L. Ramsingh, K.Murali mohan, K.Sadasiva Rao. Clinical Management of Mycotic Endometritis in Cows. International Journal of Pharmaceutical Science, 2013; 2(1): 03-04

[24] Ijapure, K. P.; Sigh, B. K. \& Chauhan, R. A. S. Incidence of pathological Affections of genitalia in she goats. India Vet J, 2002; 79: 298- 299.

[25] Mcdougall, S. Effect of peipartuient disease on the Reproductive performance of New Zealand dairy cows. N.Z. Vet J, 2001; 49: 60-67.

[26] Leblanc, S.J., Duffield, T.F., Leslie, K.E., Bateman, K.G., Keefe, G.P., Walton, J.S., Johnson WH. The effect of treatment of Clinical endometritis on reproductive performance in dairy Cows. J Dairy Sci, 2002; 85: 2237-2249.

[27] Kasimanickam, R., Duffi eld, T.F., Foster, R.A., Gartley, C.J., Leslie, K.E., Walton, J.S., Johnson, W.H. The effect of a Single administration of cephapirin or cloprostenol on the Reproductive performance of dairy cows with subclinical Endometritis. Therio, 2005; 63: 818-830.

[28] K.N. Galvão. Postpartum uterine diseases in dairy cows. Anim Reprod, 2012; 9(3): 290-296.

[29] Robert Zobel. Endometritis in Simmental cows: incidence, causes, and therapy options. Turk J Vet Anim Sci, 2013 ; 37: 134-140.

[30] Sheldon IM, Bushnell M, Montgomery J, Rycroft AN. Minimum inhibitory concentration of some antimicrobial Drugs against bacteria causing uterine infections in cattle. Vet Rec, 2004; 155: 383-387.

[31] Konigsson K, Gustafsson H, Gunnarsson A, Kindahl H. Clinical and bacteriological aspects on the use of oxytetracycline and flunixin in primiparous cows with induced Retained placenta and postpartal endometritis. Reprod Domest Anim, $2001 ; 36: 247$.

[32] Dhaliwal, G. S., Murray, R. D. and Woldehiwet, Z. Some aspects of immunology of the bovine uterus related to treatments for bovine endometritis. Animal Reproduction Science, 2001; 67: 135-152.

[33] Sengupta D and Nandi PR. Effect of estradiol, vitamin A, E and selenium treatment with varying sexual rest period on recovery rate in cross-bred cows with chronic endometritis. Vet World, 2013; 6(2):106-108. 